\title{
The Effect of Enterprise Risk Management (ERM) on Firm Performance: Evidence from the Diversified Industry of Sri Lanka
}

\author{
Kingsley Karunaratne Alawattegama \\ Huazhong University of Science and Technology, School of Management \\ 1037 Luoyu Rd, Hongshan Qu, Wuhan Shi, Hubei Sheng, China, 430073 \\ E-mail: karunratne@gmail.com
}

\author{
Received: Oct. 28, $2017 \quad$ Accepted: Nov. 21, $2017 \quad$ Published: January 1, 2018 \\ doi:10.5296/jmr.v10i1.12429 URL: https://doi.org/10.5296/jmr.v10i1.12429
}

\begin{abstract}
The objective of this empirical study is to explore the effect of the adoption of ERM on the performance of the diversified industry of Sri Lanka. The extent of the adoption of ERM is assessed based on eight ERM functions recognized by the ERM integrated framework of the committee of sponsoring organization of the Treadway Commission and use return on equity as a proxy to measure firm performance. This study finds ERM supportive internal environment, risk-aligned objective setting, event identifications, and risk response have a positive impact on firm performance. However, none of those impacts were statistically significant. Surprisingly, empirical evidence reveals that risk assessment and control activities have a negative impact on the firm performance. Information \& communication and monitoring functions indicate a significant impact on firm performance. Nevertheless, monitoring function shows a negative impact on the firm performance. The researcher believes this negative impact is attributable to the increased cost of monitoring activities that is crucial for a diversified business setup. This empirical evidence induces the researcher to conclude that, except for communication and monitoring, the adoption of ERM has no significant impact on the firm performance. These findings are contradictory with the findings of prior researchers.
\end{abstract}

Keywords: Chief risk officer, COSO, Enterprise risk management, Firm performance, Integrated risk management, Return on equity. 


\section{Introduction}

Enterprise Risk Management (ERM) has been widely discussed by both researchers and the practitioners as a holistic and effective approach to managing the wider range of risks faced by business firms. It is expected that effective risk management practices enable business managers creating and protecting long term firm value and assuring the long term stability and growth. Especially, in the context of global financial crisis (2008) and corporate scandals and high profile corporate failures (Enron, WorldCom, etc.), the concept of ERM gained an increased attention among corporate managers. Prior to the emergence of the concept of ERM as a holistic approach to manage the risk, business firms used to manage their risk factors on "case by case" basis which said to be a traditional and less effective approach. Despite the fact that ERM has been widely discussed as a holistic and modern approach to managing risks little evidence is visible as to whether ERM supports creating firm value. Though, some researchers have researched on this paradigm their findings have ended with contradictory results. Many prior studies of ERM have mainly focused on the determinants of ERM adoption and their impact on the firm performance. Nevertheless, the presence of the determinants of ERM adoption does not effectively represents the quality of the ERM adoption of an organization. To the contrary, this study explores the impact of the adoption of the ERM practices on the firm value by assessing the effectiveness of the ERM adoption based on the eight key ERM functions as suggested by the ERM integrated framework of the committee of sponsoring organization (COSO) of the Treadway Commission of USA.

\section{Literature review}

The concept of ERM has gained an attraction of the modern corporate managers as a holistic and an effective approach to managing a wider range of risk factors facing by business firms. Prior to the emergence of the concept of ERM, the organizations used to adopt a traditional silo based risk management where the risk factors were assessed and responded on an individual basis. The demand for sound internal controls, risk management and corporate governance was emerged in 1990's in the context of global economic crises and big corporate failures owing to corporate scandals and governance issues. The committee on sponsoring organization (COSO) of Treadway Commission has contributed immensely towards initiating and developing a sound integrated ERM model. According to the enterprise risk management - integrated framework, developed by the COSO (2004), ERM is defined as: "a process affected by an entity's board of directors, management and other personnel, applied in strategy setting and across the enterprise, designed to identify potential events that may affect the entity, and manage risk to be within its risk appetite, to provide reasonable assurance regarding the achievement of entity objectives". The traditional silo based risk management is said to be highly inefficient and less supportive for the top management in making long term strategic decisions in a turbulent and competitive business environment. To the contrary, ERM is recognized as a holistic and strategic approach to managing risk face by a business firm that support top management in making risk adjusted decisions for long term value creation. According to Beasley et al. (2008) ERM promotes the awareness of the sources of risks and address them by improving strategic and operational decision making. They further state that, as a result of improved efficiency, firm performance should increase, and cost of 
capital should be reduced thus firm value should increase. According to Lawrence et al. (2009), they state that there is a growing support for the general argument that organizations improve their performance by employing the ERM concept. While, the findings of some researchers confirm that ERM has a positive impact on the firm value, some other researchers highlight the fact that adoption of ERM has no value implication on firms or its value relevance depends on the contextual factors. In a study on "the effects of ERM on firm performance" , Pagach et al. (2010), fail to support for the proposition that ERM is creating for the firm . Further, the empirical studies by Papee et al. (2010), Quon et al. (2012) Otieno (2012), Tahir et al. (2011) and Li et al. (2014) fail to support the theoretical expectation that ERM has a positive impact on firm performance. Prior researches suggest, despite the corporate managers expect that the adoption of ERM would increase the firm value; there are a limited number of empirical studies on the value paradigm of ERM. It seems that the existing literature on the ERM value relevance provides contradictory results. Many of the prior researchers have focused on the determinants of ERM and assess the ERM value relevance using indicative variables of ERM adoption without extensively assessing the impact of ERM implementation effectiveness of on the firm value. According to Monda et al (2013), the academic literature on ERM is focused on two main aspects: the analysis of the factors that influence ERM adoption and its effects on firms' performances. They further argue that no studies have been conducted yet to propose robust and rigorous models to evaluate the quality and the maturity level of ERM programs implemented by firms.

Diversification has been widely recognized as a corporate strategy to create and preserve the firm value and the modern risk management theories recognize that firms with diversified business operations experience a greater risk exposure owing to its scale and complexities. The objective of this empirical study is to explore as to whether the adoption of enterprise risk management (ERM) practices affect the performance of the diversified industry. Modern business organizations that are driven by the pristine capitalistic ideology primarily aim at maximizing its shareholder value. Corporate managers and strategy developers, who are striving towards maximizing firm value recognizes diversification as a strategic option for long term growth of a firm. According to Hitt and Hoskisson (2005), latest trend across the globe is for companies to diversify. The extent of the diversification of a firm has an impact on the firm value. The proposition whether the diversification creates or destroys the firm value has long been researched by researcher and finds contradictory result. The net effect of the diversification is resulted from the tradeoff between the cost and benefits associated with the diversification strategy. According to Michel and Shaked (1984), diversifying into related business results a higher return. Shleifer and Vishny (2006), state that the firms should not opt for diversification, unless synergy can be expected. According to the general theory of risk-return correlation, as long as the diversification has an impact on the return, it has an impact on the risk as well. To this effect, this study explores the impact of the enterprise risk management paradigm in the context of the diversified business environment.

The inherent nature and the complexity in the operations of a diversified company imply that adoption of ERM is more relevant to manage its risk. A firm may add value if the diversification is expected to bring some synergies, economy of scales, an opportunity to 
better use of strategic capabilities, etc. across the strategic business units and group as a whole. Nevertheless, there are some inherent value destroyers associates with the diversification strategy. Diversification strategy will result in increased complexity of a business operation, which is more prominent with respect to the diversifications that are unrelated and conglomerate in nature. This increased complexity result an extra pressure on the corporate managers with respect to strategic risk management. According to Johson, Scholes and Wittington (2008), there are several ways that a parent company may destroy the value that is expected to derive from the diversification. Adding management costs, the cost of increased bureaucracy and obscuring financial performance, etc. are the several ways that a parent company's involvement could destroy the value. According to the growth strategies suggested by Ansoff (1957), among others (market penetration, product development, market development), diversification strategy is recognized as the most risky strategy. As such, firms that are pursuing the diversification strategy required to highly concerned on the firm's risk management strategy. It is unavoidable that the diversified business firms expand their business scope letting more external environmental factors influencing on their wider business scope. Thus, the diversification strategy needs to greatly rely on the adoption of an effective enterprise risk management function. In this context, this study presumes that the adoption of ERM is more relevant and visible in the diversified industry that induces the researcher to explore the value relevance of the ERM implementation in the diversified industry in Sri Lanka.

Adoption of ERM is expected to add value to a business firm in different ways. Nevertheless, some researchers emphasize that the implementation of a sound ERM function would result a significant cost to the firm value that will dilute the benefits that would be expected from the diversification strategy. There are different factors that destroy the value of a diversified firm such as diseconomy of scales, agency costs, increased regulatory and compliance costs and more importantly the cost of implementing a firm wide integrated ERM function that significantly erode the firm value. According to Jing, Bajtelsmit \& Wang (2014), ERM adoption and implementation activities are both costly and time consuming and the quality of implementation will differ from firm to firm. Thus, the net impact resulting from the adoption of ERM on the value of a diversified firm is depending on the cost-benefit tradeoff associate with ERM implementation. This study explores as to whether the adoption of ERM has an impact on the firm value in the diversified industry.

Many of the prior researchers who explored the value relevance of ERM have relied, to a great extent, on indicative variables and the determinants of the ERM implementation their impact on the firm performance. For example, according to Liebenberg \& Hoyt, 2003; Beasley et al (2008); Hoyt et al. (2008), Hoyt et al. (2011), Pegach et al. (2008), Pegach et al. (2010); Pegach et al. (2011), the presence of a CRO/CEO, big four audit firm, audit committee, risk committee, institutional investor are deemed to be indicative variables of the ERM implementation and shows a positive impact on the firm performance. Nevertheless, this approach has been criticized by some researchers such as Hoyt et al, (2008), Tjahjono (2017) and Jing et al. (2014) who argue that ERM determinants and the indicator variables do not represent the ERM implementation effectiveness of an organization. For example, 
according to Jing, Bajtelsmit \& Wang, (2014), “prior studies primarily focus on the determinants of ERM adoption and the problem with this literature has been that ERM adoption is not equivalent to ERM quality, making it difficult to assess value effects". This study aims to empirically verify the effect of the adoption of ERM practices on firm performance by assessing the adoption of ERM using a robust model suggested by the committee on sponsoring organizations (COSO) of the Treadway Commission.

\section{Data Collection and Methodology}

\subsection{Sample and data collection}

Seventeen companies listed on the Colombo Stock Exchange under the diversified sector, representing approximately $25 \%$ of the market capitalization (as of September 2016), are included in the sample. Both primary and secondary data are considered for this empirical study. Primary data are collected by distributing a survey questionnaire among those people whore are engaged in financial and risk management functions of the selected observing firms. Fifty six completed questionnaires were qualified and included in the analysis. Survey questionnaire assesses the extent of ERM adoption by the observing firms using forty questions (five-point Likert scale) on eight ERM functions recommended by the COSO's ERM integrated framework. Firm performance, the dependent variable, is measured using return on equity (ROE) which is widely used as a proxy to firm value. Secondary date required to measure the ROE is gathered using published annual report that are available on the CSE official website. Annual audited financial statements, that are an integral part of the annual report, are considered as a reliable source to gather financial information about firm performance

The committee of sponsoring organization recognizes that an organization needs to implement eight functions that are vital for effective implementation of a sound ERM system. Accordingly, this study explores the internal environment (IE), objective setting (OS), even identification (EI), risk assessment (RA), risk response (RR), control activities (CA), information and communication (IC) and monitoring (M) as the key functions requires for a company to implement a sound ERM model. This study assesses, through the survey questionnaire, to what extent the observing firms are adopting those key ERM functions. This study uses a five scale questionnaire that lets the respondents to choose between, "strongly disagree," "disagree," "neutral," "agree" and "strongly agree" on the level of adoption of ERM functions that best fit for their firm. If the respondent strongly disagree with the statement relating to the particular ERM function a numerical value of " 1 " is assigned and if strongly agree with the stated risk management practice a numerical score of " 5 " is assigned. For other responses, i.e. disagree, neutral and agree, scores of 2, 3 and 4 were assigned respectively. This survey questionnaire was developed by considering the prior research works of Beasley et al. (2005), Gates et al. (2012), Njagi (2015), Altermeyer (2004). In line with the prior researchers' works, the researcher is confident that the methodology adopted in this study to measure the extent of ERM implementation provides a reasonable and theoretical basis for assessing the degree of ERM adoption by the diversified industry in Sri Lanka. 


\subsection{Theoretical framework}

The conceptual framework that is used to work out the study is given in the Figure 1. This conceptual model is developed based on the prior researchers' works and directions.

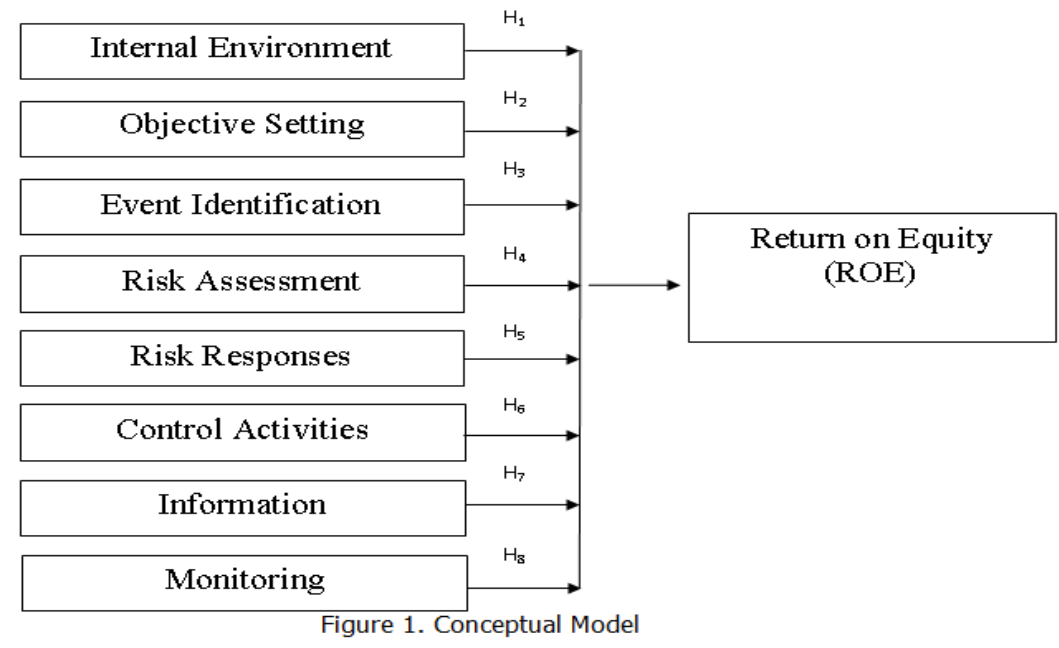

\subsection{Defining and measurement of independent and dependent variables}

\subsubsection{Return on equity (Dependent variable)}

Return of equity (ROE) is popularly used as a proxy to measure financial performance of a company. This study measures ROE by dividing the net profit attributable to equity holders of the company, i.e. profit after tax, by the closing book value of equity. Many of the prior researcher who engage in similar studies use the ROE as a tool for measuring firm performance. For example, Demsetz, and Lehn 1985Lo, 2003 and Brown et al., 2005 as cited by Chagadhari \& Chaleshtori, 2001, Bebchuk and Cohen 2004 as cited by Brown and Caylor 2004 and Mork, Shleifer and Vishny 1988;).

\subsubsection{Internal Environment (IE)}

ERM supportive internal environment is the context within which the ERM function is implemented that affects the effectiveness of the whole ERM system. So, $t$ is a fundamental requirement for a successful implementation of an effective ERM approach. According to COSO's report on ERM, the internal environment represents the "tone of the top management" that encompasses the management attitude and awareness about the importance and the relevance of the ERM towards creating and preserving the value of the firm. Kinyua et al. (2015), they recognize that there is a significant association between internal control environment and financial performance. According to Liebenberg and Hoyt (2003), they state that the presence of chief risk officer strengthens the firm's ERM internal environment and adds value to the firm. In this context, it is believed that ERM supportive internal environment facilitates a culture of risk aligned decision making that would positively affect the firm performance and following hypothesis is derived, 
H1: ERM supportive internal environment has a positive impact on the ROE of the diversified firms.

\subsubsection{Risk aligned Objective Setting (OS)}

The level of risk to which a firm is exposed is dependent on the amount of return it expects to earn. The expected return is reflected in a firm's objectives. The point when management sets its objectives is the point they set their risk exposure. In a diversified business setup, it has wider business scope with competing business objectives that poses a greater extent of risk exposure than an undiversified business. According to Gates et al. (2013) most ERM frameworks assert that risk should be identified in relation to the firm's objectives. The ERM integrated framework of COSO (2014), recognizes that a firm's objectives should be aligned within the company's risk appetite and risk tolerance levels. According to Hoyt \& Liebenberg (2011), ERM strategy aims to reduce volatility by preventing aggregation of risk across different sources. Risk aligned objective setting allows the top management to consider risk at the time of setting the firm's long term objectives. So they need to set their objectives by considering the corresponding risk of achieving them. In this context, following hypothesis is derived with respect to risk aligned objective setting;

H2: Risk aligned objective setting has a positive impact on ROE of diversified firms.

\subsubsection{Event Identification (EI)}

Changing environment creates lots of events that could either favorably or unfavorably affect the achievement a firm's objectives. Most of these external environmental changes create either a threat or an opportunity for a business that directly affect the risk exposure of a firm. Owing to the nature of the wider scope of diversified business enterprise event identification is very crucial for implementing a successful integrated ERM system. According to Beasley et al. (2008), minimizing business surprises will minimize volatility in return and will improve the firm value. Kiprop et al., (2017) state that there is a positive relationship between risk identification and performance of financial institutions. Events identification enables an organization to foresee the favorable and unfavorable internal and external events affecting the achievements of the objectives of the entity that minimizes the risk of facing business surprises that adversely affect the performance. In this context, researcher derives the third hypothesis as below,

\section{H3: Event identification has a positive impact on ROE of diversified firms}

\subsubsection{Risk Assessment (RA)}

Events that would affect either positively or negatively make no sense if their likelihood of occurring and the resulting impact on firm performance is relatively very low. Thus, in order to develop effective risk responding strategy management needs to assess the plausibility of risky events in the context of their likelihood and impact on firm performance. Solomon \& Muntean, (2012), state that a company's risk assessment on the basis of leverage coefficients is required for the predicted behavior analysis for estimating future results. According to Deloitte \& Touche LLP; Curtis and Carey (2012), Risk assessment is important since it is the 
way in which enterprises get a handle on how significant each risk is to the achievement of their overall goals. So, with respect to risk assessment, researcher derives the following hypothesis,

H4: Risk assessment has a positive impact on ROE of diversified firms.

\subsubsection{Risk response (RR)}

Based on the risk assessment and in the context of the firms risk tolerance and risk appetite, management needs to decide a suitable strategy in response to the assessed level of risk. These strategies include choosing among the risk avoidance, risk acceptance, risk sharing and risk reduction. According to Vollmer (2015), effective risk responding strategy is expected to have a positive impact on the firm performance. This induces the researcher to derive the fifth hypothesis of this study as below;

H5: Risk response has a positive impact on ROE of diversified firms.

\subsubsection{Control activities (CA)}

Development and implementation of a sound internal control system, enhance the effectiveness and efficiency of business operations. It usually aims at ensuring that the operations are performed as they are planned by the management and ensuring its effectiveness and efficiency. It also acts as a deterrent of possible instances of frauds. According to Munene (2013), his findings established a significant relationship between internal control system and financial performance. Further, according to Eniola and Akinselure (2016), they state that effective internal controls will significantly improve financial performance by helping the organization to significantly reduce fraud perpetration. Control activities usually strengthen the firm's internal control functions, which in return enhances the efficiency and effectiveness of the operations affecting positively on the firms' performance. In this context, this study derives following hypothesis;

H6: Control activities have a positive impact on ROE of diversified firms.

\subsubsection{Information and Communication (IC)}

The integrated risk management is appraised over traditional silo based risk management owing to its integration of risk information that facilitate risk-aligned strategic decision making. Establishing and implementing an effective information and communication channel is vital to achieve the intended benefits of an integrated risk management framework and it can only be achieved by ensuring an effective integration of information across the organization. According to Eikenhout ( 2015), the improvement in the information of the organization's risk profile is another potential source of value created by ERM. Further, Fisher and Kenny (2000), as Cited by Olugbode et al. (2008), suggest that organizations infuse information systems into their operations so as to enhance competitiveness and facilitate business growth and success. According to Chaffey and Wood 2005 as Cited by Olugbode et al. (2008), when the communication is thorough and accurate, decisions tend to be more informed and effective. These literatures emphasize that it is apparent that enhanced communication of risk information lets the organizational managers to make 
informed and risk aligned decisions which leads towards achieving better performance. In the context of a diversified business setup with several strategic business units, information and communication becomes even more crucial and vital for the success of the business. In this context study derives the following hypothesis;

H7: Information and communication of risk information has a positive impact on ROE of diversified firms.

\subsubsection{Monitoring (M)}

Overall ERM functions are required to be closely supervised and monitored on a regular basis to ensure that the intended benefits of the ERM system is effectively achieved. Prior researchers on corporate and good governance recognize that monitoring and supervising are a vital for better organizational performance. For an instance, Wholey (2010), states that monitoring and evaluation are used in government to increase transparency, strengthen accountability, and improve performance. Monitoring function should be an ongoing process and timely evaluation of its effectiveness aiming to decide as to whether further modifications are required for the effective implementation of a firm's risk management system. According to Mutinda and Kiruja, (2015), the monitoring and evaluation (M\&E) systems and structures are often linked to public service reform initiatives in budgeting and accountability. In this context, it is evident that the effective and ongoing monitoring of a firm's key ERM functions ensures the achievement of the intended objectives of each function. So, the researcher develops the following hypothesis with respect to monitoring function

H8: Monitoring of ERM functions has a positive impact on ROE of diversified firms.

\subsection{Regression model}

In order to test the impact of the eight ERM functions of the COSO's ERM framework, on the firm performance and to assess the relationship between the adoption of the ERM practices and the firm performance, this study adopts following regression model.

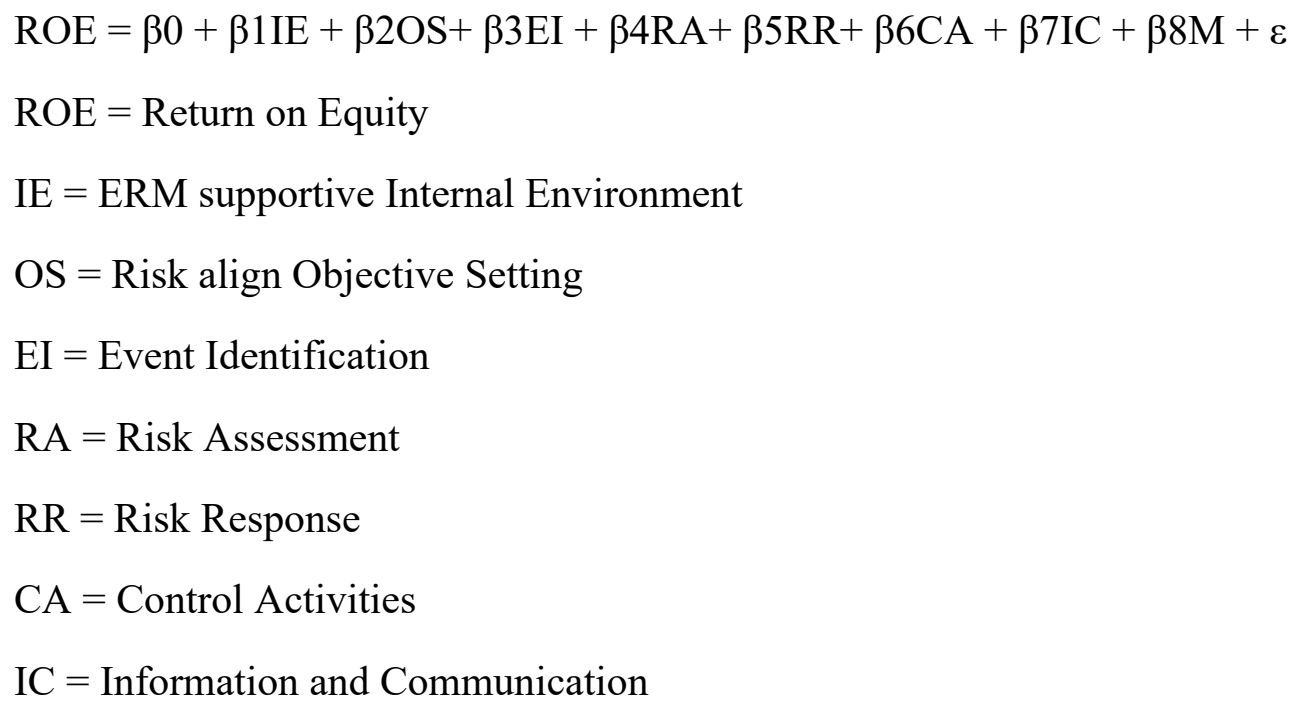


$\mathrm{M}=$ Monitoring

$\varepsilon \quad=$ Error term

\section{Results and discussion of findings}

\subsection{Sample content}

Demographic characteristics of the respondents and companies are presented in the Table 01 . This descriptive data table captures key indicators of the respondents and the observing companies of the diversified industry. Many of the respondents are in their middle age category representing lower and middle level management layers of the observing companies. The majority of the respondents possess a bachelor degree or related professional qualifications in the fields of accounting and finance that imply their academic rigor. Respondents were given an opportunity to make a judgmental assessment, based on their perception about the maturity level of their ERM function, in order to assess the perceived maturity level of the firms' ERM. Approximately, 18 percent of the respondents stated that their firm identify, assess and control strategic, financial, operational, compliance risks and ERM is an integral part throughout the organization. Sixty two percent of the respondents are of the view that their firms identify, assess and controls strategic, financial, operational and compliance risks and are in the process of implementing a complete ERM system. Five observing firms, out of the total sample of 17 firms, are having a chief risk officer (CRO). Eighty eight percent of the firms have engaged one of the big four auditors as their external auditors whose presence, facilitate diversified firms to adopt ERM where necessary seeking the external auditors consultations. Approximately, $65 \%$ of the observing firms had an institutional shareholder as its major shareholder. The presence of the institutional shareholder generally positively affects the shareholder activism and greater commitment by the board of directors regarding preserving best practices of corporate governance and risk management. 
Table 1. Sample content

\begin{tabular}{|c|c|c|}
\hline Variable & No. of respondents & Percent (\%) \\
\hline \multicolumn{3}{|l|}{ Age category of respondents } \\
\hline Less than 30 years & 31 & $55.4 \%$ \\
\hline $30-40$ years & 23 & $41.1 \%$ \\
\hline $40-50$ years & 2 & $3.6 \%$ \\
\hline \multicolumn{3}{|l|}{$\begin{array}{l}\text { Academic / Professional Qualifications } \\
\text { (highest) }\end{array}$} \\
\hline MBA & 32 & $57.1 \%$ \\
\hline $\mathrm{ACCA} / \mathrm{CA} / \mathrm{CFA} / \mathrm{CIMA} / \mathrm{CA}$ & 22 & $39.3 \%$ \\
\hline Bachelor & 2 & $3.6 \%$ \\
\hline \multicolumn{3}{|l|}{$\begin{array}{l}\text { Perceived maturity level of observing } \\
\text { company's ERM practices }\end{array}$} \\
\hline $\begin{array}{l}\text { Manage risk in specific areas, no plans } \\
\text { exist to implement a completes system of } \\
\text { ERM }\end{array}$ & 6 & $10.7 \%$ \\
\hline $\begin{array}{l}\text { Identify, assess and control risk in } \\
\text { specific areas and we are planning to } \\
\text { implement a firm wide ERM system }\end{array}$ & 5 & $8.9 \%$ \\
\hline $\begin{array}{l}\text { Identify, assess and control strategic, } \\
\text { financial, operational and compliance } \\
\text { risks and we are in the process of } \\
\text { implementing a complete ERM system }\end{array}$ & 35 & $62.5 \%$ \\
\hline $\begin{array}{l}\text { Identify, assess and control strategic, } \\
\text { financial, operational, compliance risks } \\
\text { and ERM is an integral part throughout } \\
\text { the organization }\end{array}$ & 10 & $17.9 \%$ \\
\hline \multicolumn{3}{|l|}{ Presence of chief risk officer } \\
\hline Yes & 5 & $29.4 \%$ \\
\hline No & 12 & $70.6 \%$ \\
\hline \multicolumn{3}{|l|}{ Presence of audit committee } \\
\hline Yes & 17 & $100 \%$ \\
\hline \multicolumn{3}{|l|}{ Presence of Big four auditor } \\
\hline Yes & 15 & $88.2 \%$ \\
\hline & 2 & $11.8 \%$ \\
\hline \multicolumn{3}{|l|}{ Presence of Institutional shareholder } \\
\hline Yes & 11 & $64.7 \%$ \\
\hline & 6 & $35.3 \%$ \\
\hline
\end{tabular}

\subsection{Descriptive statistics of the existing levels of independent and dependent variables}

The descriptive statistics with respect to the existing levels of return on equity (ROE), ERM supportive internal environment, risk-aligned objective setting, event identification, risk assessment, risk response, control activities, information and communication and monitoring 
are presented in Table 2. With respect to the dependent variable, i.e. the return on equity (ROE), which is used as a proxy to measure the financial performance of observing companies, the mean values for three years average ROE is 0.075 . The highest and lowest values for the same are 0.24 and -0.19 respectively. The mean value for control activities stands above 4 . That implies the control activities are very crucial for diversified business operations owing to the inherent nature of the risk due to the increased complexity of the business structure. With respect to the other functions i.e the ERM supportive internal environment, risk-aligned objective setting, event identification, risk assessment, risk response, information and communication and monitoring were between from 3.6 to 4 . This brings into light that the adoptions of those risk management functions in the diversified industry are at a moderately high level.

Table 2. Descriptive statistics

\begin{tabular}{lcccc}
\hline \multicolumn{1}{c}{ Variable } & Minimum & Maximum & Mean & Std. Deviation \\
\hline Return on equity & -.19 & 0.24 & 0.0747 & .11364 \\
ERM supportive internal environment & 3.15 & 4.53 & 3.9206 & .37405 \\
Risk aligned objective setting & 3.15 & 4.40 & 3.9510 & .33080 \\
Event identification & 2.93 & 4.33 & 3.8311 & .30095 \\
Risk assessment & 2.70 & 4.20 & 3.7176 & .37553 \\
Risk response & 3.20 & 4.20 & 3.7706 & .26323 \\
Control activities & 3.47 & 4.60 & 4.0539 & .35846 \\
Information and communication & 2.85 & 4.20 & 3.6000 & .40143 \\
Monitoring & 2.65 & 4.20 & 3.6924 & .39148 \\
\hline
\end{tabular}

\subsection{Correlation Analysis}

Correlation analysis assesses the as to whether the independent variables and dependent variable associate in a linear relationship. The degree of the strength of the relationship between the independent and dependent variables is measured by Pearson's correlation coefficient and is usually denoted by " $r$ ". Correlation coefficient ( $r$ ) can take a range of values from +1 to -1 . A correlation coefficient value of "zero" indicates that there is no association between the independent and dependent variables. A coefficient value greater than zero indicates a positive association, it means an increase in the independent variable will result in an increase in the dependent variable, vice versa. The Pearson's correlation coefficient and the coefficient for regression analysis are presented in Table 3 and Table 4 respectively. It is theoretically expected that there is a strong positive relationship between the adoption of ERM functions and on firm performance as measured by the ROE. Nevertheless, surprisingly the results of the statistical analysis indicate that there is a weak relationship between the extent of the adoption of ERM functions and the firm performance and with a negative relationship in some cases. When it comes to consider the significance level between the two variables, according to statistical output, all $\mathrm{P}$ values are greater than 0.05 . So, it can be concluded that none of the ERM functions have a significant relationship with firm performance. Nevertheless, Pearson's correlation coefficient does not assess the causal impact of the independent variables. In order to assess the impact of the adoption of ERM 
functions on the firm performance researcher needs to analyze the regression coefficients. The summary of the regression analysis output is given in the Table 4.

Table 3. Pearson's correlation

\begin{tabular}{ccc}
\hline ERM practices & & Return on Equity \\
\hline ERM supportive internal environment & Pearson Correlation & .154 \\
Risk aligned objective setting & Sig. (2 - tailed) & .556 \\
Event identification & Pearson Correlation & -.003 \\
& Sig. (2 - tailed) & .991 \\
Risk assessment & Pearson Correlation & .010 \\
& Sig. (2 - tailed) & .968 \\
Risk response & Pearson Correlation & -.027 \\
& Sig. (2 - tailed) & .917 \\
Control activities & Pearson Correlation & .054 \\
& Sig. (2 - tailed) & .837 \\
Information and communication & Pearson Correlation & -.129 \\
& Sig. (2 - tailed) & .621 \\
Monitoring & Pearson Correlation & .421 \\
\end{tabular}

Table 4. Coefficient for regression model

\begin{tabular}{|c|c|c|c|c|c|}
\hline \multirow{2}{*}{ Model of ROE } & \multicolumn{2}{|c|}{$\begin{array}{c}\text { Un-standardize } \\
\text { Coefficient }\end{array}$} & \multirow{2}{*}{$\begin{array}{c}\text { Standardized } \\
\text { Coefficient } \\
\text { Beta }\end{array}$} & \multirow{2}{*}{$\mathrm{t}$} & \multirow{2}{*}{ Sig. } \\
\hline & $\mathrm{B}$ & Std. error & & & \\
\hline (Constant) & -.548 & .297 & & -1.841 & .103 \\
\hline ERM supportive internal environment & .082 & .081 & .271 & 1.016 & .339 \\
\hline Risk aligned objective setting & .066 & .109 & .193 & .606 & .562 \\
\hline Event identification & .075 & .068 & .199 & 1.109 & .300 \\
\hline Risk assessment & -.019 & .112 & -.063 & -.168 & .870 \\
\hline Risk response & .100 & .092 & .233 & 1.092 & .306 \\
\hline Control activities & -.149 & .074 & -.470 & -2.005 & .080 \\
\hline Information and communication & .387 & .069 & 1.368 & 5.611 & .001 \\
\hline Monitoring & -.365 & .110 & -1.258 & -3.321 & .011 \\
\hline
\end{tabular}

\subsection{Hypothesis testing}

The direction and the strength of the linear relationship between the independent and dependent variable is measured by the Pearson's correlation (Bruin, 2006). Nevertheless, it fails to assess the impact on the dependent variable in the presence of other variables. The causal relationships between each ERM function along with the presence of other ERM functions are assessed by the regression model. In order to assess the causal impact of the 
adoption of ERM functions on the firm performance, the researcher needs to assess the regression result by testing the hypothesis. The coefficient for internal environment (IE) is positive 0.082 , but not statistically significant $(p>0.05)$. Since the $p$ value.339 is greater than 0.05 , the researcher has no enough evidence to say that ERM supportive internal environment has an impact on firm performance as measured by the ROE. This result is contradictory with the findings of some prior researchers who found that ERM supportive internal environment has a positive and significant impact on ROE. For instance, Liebenberg et.al (2003) and Kinyua et al, (2015) finds that the ERM supportive internal environment adds value to the firm and there is a significant association between internal control environment and financial performance. Nevertheless, this result is consistent with $\mathrm{Li} \mathrm{Wu}$ et al. (2014), whose empirical study on enterprise risk management and firm value within China's insurance industry reveals that ERM functions make no significant impact on the firm value. With respect to the second hypothesis $\left(\mathrm{H}_{2}\right)$ that postulates the risk-aligned objective setting has a positive impact on the firm performance; the $p$ value is 0.562 , which is greater than 0.05 . This implies that the researcher has no enough evidence to say that risk aligned objective setting has a positive impact on firm performance. This regression result is inconsistent with the findings of Beasley et al. 2005; Liebenberg \& Hoyt, 2003 and Pegach \& Warr, 2011. Nevertheless the result is consistent with Rao et al. (2007) who assert in their survey of executives and managers that there is dissatisfaction with the link between ERM and strategy setting. The third hypothesis (H3) hypothesize that the event identification (EI) has a positive impact on the return on equity. The coefficient for event identification is -.075 that implies, assuming all other variables remained constant increase in event identification will result decrease in ROE. Nevertheless, this relationship is not statistically significant since the $p$ value is .300 which is greater than 0.05 . So, this study finds no enough evidence to say that event identification has a significant impact on ROE. This result contradicts with the findings of Beasley et al. (2008) who assert that effective ERM implementation lets the organizations to foresee the risky events and consequently, minimizing business surprises and volatility in return allowing a firm enhancing its value.

This study fails to find enough evidence to say that the risk assessment and risk response has significant impact on firm performance. As far as the effect of risk assessment (RA) on ROE is concerned, it has a negative impact on firm performance with a regression coefficient of-.019 and risk response (RR) has a positive impact on firm performance with a beta coefficient of positive 0.1. Nevertheless, none of the risk assessment and risk response predictor variables have a relationship with ROE that is statistically significant ( $p$ value for both RA and RR is greater than .05). So, the researcher has no enough evidence to say that risk assessment and risk response have an impact on ROE. This result is consistent with freewheeling opportunists' theory of strategic management. Freewheeling opportunists do not greatly rely on risk aligned strategic planning, instead they identify market opportunities as they arise and take corrective and remedial actions for risky events as they are emerging. According to Steffan (2008), freewheeling opportunism is a concept that suggests a company does not need formal business planning, instead it should remain open to opportunities as they arise and led by market conditions and events therefore adapting to changes required in order to exploit the changing market conditions to gain a competitive advantage. 
The sixth hypothesis $\left(\mathrm{H}_{6}\right)$ expects that control activities have a positive impact on the return on equity. Nevertheless, the beta coefficient value of control activities is negative 0.149 with $p$ value .08 which is greater than 0.05 . These results suggest this study has no enough evidence to say that control activities have a positive impact on return on equity. Risk management theory expects that improved control activities result improved efficiency and positive impact on firm performance. But the result of this study finds it's opposite. This negative relationship could be due to the additional cost of implementing a sound internal control system which may out-weight the expected incremental benefits. With respect to the predictor variable information and communication, this study finds a positive impact on return on equity with a beta coefficient of .387. Regression coefficient indicates that information and communication has a positive and statistically significant impact on return on equity. The $p$ value of information and communication variable is .001 which is less than 0.05. As such the researcher can conclude that information and communication has a significant impact on firm performance with a 95\% confidence level. The predictor variable of monitoring of ERM functions has a negative impact on firm performance with a beta coefficient of -.365 that is statistically significant with a $p$ value of .011 which is lower than the cutoff significance level of .05 . These results induce the researcher to conclude that monitoring activities of diversified business enterprises have a negative impact on their firm performance. These findings confirm the arguments that assert, the diversification destroys firm value by the increased monitoring and administrative cost to the group.

\section{Conclusions}

Business firms in the diversified industry face increased level of business risk owing to its wider business scope and cultural, geographical and operational diversity. Enterprise risk management theories suggest that business organizations with high risk exposure could seek benefits by adopting an integrated enterprise risk management system. This study was conducted with objective of exploring as to whether the extent of adoption of ERM functions, suggested by the COSO's ERM integrated framework, has an impact on the financial performance of firms in the diversified industry. This study tested the ERM integrated model of COSO by assessing the extent of adoption of its eight key ERM functions by the diversified business firms in Sri Lanka and its impact on their performance as measured by the return on equity. This study finds six ERM functions out of eight key functions make no significant impact on the performance of the diversified firms.

The ERM supportive internal environment, risk aligned objective setting, Event identifications, and risk response show a positive impact on firm performance. However, none of those impacts were statistically significant. Surprisingly, empirical evidence reveals that risk assessment and control activities have a negative impact on the firm performance. Nevertheless, none of those functions have a significant impact on firm performance. Information \& communication and monitoring functions were the only ERM functions that show a significant impact on firm performance. However, monitoring function indicates that it has a negative impact on the firm performance. The researcher believes this negative impact is attributable to the increased cost of monitoring activities that is crucial for a business engaged in a diversified business setup. These empirical evidences induce, 
researcher to conclude that except for communication and monitoring the adoption of ERM has no significant impact on the firm performance. The empirical evidence of this study is contradictory with the theoretical expectation that adoption of ERM practices has a positive impact on firm performance confirmed by Beasley et al. (2008), Hoyt et al. (2010), Pegach et al. (2011), Bouaziz (2012), Stanley (2011), Mountiho (2012) and Najjar (2015). Nevertheless, as far as the findings of some other researchers such as Papee et al. (2010), Quon et al. (2012) Otieno (2012), Tahir et al. 2011, Li et al. (2014), and Pagach et al. (2010), are concerned, empirical evidence of this study is consistent with their findings. Literature on the impact of ERM on firm performance shows that prior researchers, who find ERM has a positive impact on firm performance, have greatly relied upon dummy variables, such as the presence of CRO, big four auditors, risk committee, institutional shareholder etc, when assessing the extent of ERM implementation. The findings of this study imply that those dummy variables could not effectively assess the extent ERM adoption by a firm. Thus, it is recommended for future researchers to assess the value relevance of enterprise risk management using a robust and in-depth study.

\section{References}

Altermeyer, L. (2004). Assessment of Texas State Government: Implementation of Enterpriser Risk Management Principles, Applied research projects, Texas State University-San Marcos. https://digital.library.txstate.edu/handle/10877/3593

Ansoff, I. (1957). Strategies for Diversification. Harvard Business Review, 35(5), 113-124

Beasley, M.S., Branson, B.C., \& Hancock, B.V., (2010), Current state of enterprise risk oversight and market perception of COSO's ERM framework, COSO's Report on ERM.

Beasley, M.S., Pagach, D., \& Warr, R. (2008). The information conveyed in hiring announcements of senior executives overseeing enterprise-wide risk management process. Journal of Accounting, Auditing and Finance, 23(3), 311-332. https://doi.org/10.1177/0148558X0802300303

Beasley, M.S, Clune, R., \& Hermanson, D.R. (2005). Enterprise risk management: an empirical analysis of factors associated with extent of implementation. The Journal of Accounting and Public Policy, 4, 521-531. https://doi.org/10.1016/j.jaccpubpol.2005.10.001

Beeler, J.D., J.E. Hunton, \& B. Wier. 1999. Promotion Performance of Internal Auditors: A Survival Analysis. Internal Auditing, 14(4), 3-14.

Bouaziz, Z. (2012). The impact of the presence of Audit Committees on the financial performance. International Journal of Management \& Business Studies, 2(4).

Brown, L.D., \& Caylor, M.L. (2004). Corporate governance and firm performance, https://doi.org/10.1007/s11156-007-0082-3

Bruin, J. (2006). Newtest: command to compute new test. UCLA: Statistical Consulting Group. https://stats.idre.ucla.edu/stata/ado/analysis/ 
Chagadhari, M.F., \& Chaleshtori, G.N. (2001). International conference on sociality and economic development, Conference proceedings, http://ssrn.com/abstract=2259541

COSO, Committee of sponsoring organization of Treadway commission. (2004). Enterprise risk management (ERM) integrated framework. COSO.

Deloitte \& Touche LLP, Curtis, P., \& Carey, M. (2012). Risk assessment in practice, Committee of sponsoring organization of the Treadway Commission.

Eikenhout, L. (2015). Risk Management and Performance in Insurance Companies, an un publish Master thesis. http://essay.utwente.n1/66625/1/Eikenhout_MA_MB.pdf

Eniola, O. J., \& Akinselure, O.P. (2016). Effect of Internal Control on Financial Performance of Firms in Nigeria. IOSR Journal of Business and Management (IOSR-JBM) e-ISSN: 2278-487X, p-ISSN: 2319-7668, 18(10), 80-85.

Gates, S, Nicolas, J.L., \& Walker, P.L. (2012). Enterprise risk management: A process for enhanced management and improved performance. Management Accounting Quarterly, pp.28-38. https://hal.archives-ouvertes.fr/hal-00857435

Golshan, N.M., \& Rasid, S.Z.A. (2012). What Leads Firms to Enterprise Risk Management Adoption? A Literature Review, International Conference on Economics, Business and Marketing Management.

Hitt, M., \& Hoskisson, R. (2005). Strategic management, competitiveness and globalisation: Concepts and cases (7th ed.)

Hossein, G.M., \& Mahdi, S. (2009). Corporate Governance and firm performance, Journal of Accounting Advances, 1(57/3), 113-128.

Hoyt, R.E., \& Liebenberg, A.P. (2011). The value of enterprise risk management. The $\begin{array}{llll}\text { Journal of Risk } \text { and } & \text { 7nsurance, }\end{array}$ https://doi.org/10.1111/j.1539-6975.2011.01413.x

Hoyt, R.E., Moore, D.L., \& Liebenberg, A.B. (2008). The Value of Enterprise Risk Management: Evidence from the U.S. Insurance Industry. Society of Actuaries.

ISO 31000-2009, Enterprise Risk Management. (2009). International organization for standardization.

Jing, A, Bajtelsmit, V.L., \& Wang,T. (2014). Enterprise Risk Management and Diversification Effects for Property and Casualty Insurance Companies. Enterprise Risk Management Symposium, Society of Actuaries.

Johnson, G., Scholes, K., \& Wittington, R. (2008). Exploring Corporate Strategy, Eighth edition, Prentice hall financial times.

Kinyua, J.K., Gakure, R., Gekara, M., \& Orwa, G. (2015). Effect of Internal Control Environment on the Financial Performance of Companies Quoted in the Nairobi Securities 
Exchange. International Journal of Innovative Finance and Economics Research, 3(4), 29-48, Oct-Dec.

Kiprop, L. F., \& Tenai, J. (2017). The effect of risk identification on performance of financial institutions. International Journal of Business Strategy, 1(5), 75- 87.

Li, Q., Wu, Y., Ojiako, U., Marshall, A., \& Chipulu, M. (2014). Enterprise risk management and firm value within China's insurance industry. Acta Commercii, 14(1), 10.

Liebenberg, A. P., \& Hoyt, R. E. (2003). The determinants of enterprise risk management: evidence from the appointment of chief risk officers. Risk Management and Insurance Review, 6(1), 37-52..

Lawrence A. Gordon, Martin P. Loeb, \& Chih-Yang Tseng. (2009). Enterprise risk management and firm performance: A contingency perspective, J. Account Public Policy. https://doi.org/10.1016/j.jaccpubpol.2009.06.006

Michel, A., \& Shaked, I. (1984). Does Business Diversification Affect Performance?. Journal of Financial Management, 13, 18-25. https://doi.org/10.2307/3665297

Monda, B., \& Giorgino, M. (2013). An ERM maturity model. SSRN Electronic Journal. https://doi.org/10.2139/ssrn.2198944

Moutinho, V.N. (2012). Audit fees and firm performance, Dissertation submitted to partial fulfillment of the masters in finance.

Munene, M.J. (2013). Effect of internal controls on financial performance of technical training institutions in Kenya, An un-published masters dissertation.

Mutinda , V., \& Kiruja, E. (2015). Role of monitoring and Evaluation on performance of public organization projects in Kenya: A case of Kenya Meat Commission. International Journal of Innovative Development \& Policy Studies, 3(3), 12-27, July-Sept.

Najjar, D.A. (2015). The effect of institutional ownership on firm performance: Evidence from Jordanian Firms. International Journal of Economics and Finance, 7(12). https://doi.org/10.5539/ijef.v7n12p97

Njagi, C. (2015). Evaluation of the level of enterprise risk management adoption and maturity of the insurance companies in Kenya. An MBA project report.

Olugbode, M. Elbeltagi, I. Simmons, M., \& Biss, T. (2008). The Effect of Information Systems on Firm Performance and Profitability Using a Case-Study Approach. The Electronic Journal Information Systems Evaluation, 11(1), 11-16.

Otieno, O.J. (2012). Relationship between enterprise risk management practices and financial performance of non-financial firms listed in Nairobi Securities Exchange

Paape, L \& Spekle, R.F. (2012). The adoption and design of enterprise risk management practices: an empirical study. European Accounting Review, 21(3), 533-564. https://doi.org/10.1080/09638180.2012.661937 
Pagach, D., \& Warr, R. (2008). The Characteristics of Firms that Hire Chief Risk Officers, College of Management North Carolina State University .

Pagach, D., \& Warr, R. (2010). The effects of enterprise risk management on firm performance. Electronic article, https://doi.org/10.2139/ssrn.1155218

Pagach, D., \& Warr, R. (2011). The characteristics of firms that hire chief risk officers. The $\begin{array}{llll}\text { Journal of Risk } \text { and } & \text { Insurance, } & \text { 78(1), }\end{array}$ https://doi.org/10.1111/j.1539-6975.2010.01378.x

Quon, T.K., Zeghala, D., \& Maingo, M. (2012). Enterprise risk management and firm performance. Procedia - Social and Behavioral Sciences, 62, 263-267. https://doi.org/10.1016/j.sbspro.2012.09.042

Rao, A., \& Marie, A. (2007). Current practices of enterprise risk management in Dubai, Management Accounting Quarterly, Spring. PP.10-22

Shleifer, A., \& Vishny, R.W. (1991). Takeovers in the 60's and the 80's: Evidence and Implications. Strategic Management Journal. https://doi.org/10.1002/smj.4250121005

Solomon, D.C., \& Muntean, M. (2012). Assessment of Financial Risk in Firm's Profitability Analysis. Economy Transdisciplinarity Cognition, 15(2).

Stanley, J.D. (2011). Is the Audit Fee Disclosure a Leading Indicator of Clients' Business Risk?. AUDITING: A Journal of Practice \& Theory: August 2011, 30(3), 157-179. https://doi.org/10.2308/ajpt-10049

Steffan, B. (2008). Essential Management Accounting: How to Maximise Profit and Boost Financial, Kogan Page Publishers.

Soliman, A., \& Mukhtar, A. (2017). Enterprise Risk Management and firm performance: an integrated model for the banking sector. Banks and Bank Systems (open-access), 12(2), 116-123. https://doi.org/10.21511/bbs.12(2).2017.12

Tahir, I.M., \& Razali, A.R. (2011). The relationship between enterprise risk management (ERM) and firm value: Eveidence from Malaysian public listed companies. International journal of economics and management sciences

Tjahjono, S. (2017). Enterprise Risk Management Implementation Maturity in Financial Companies. Etikonomi, 16, 173-186. https://doi.org/10.15408/etk.v16i2.5440

Vollmer, S. (2015). 6 steps to manage risks and drive performance, CGMA Magazine

Wholey, J., Hatry, H., \& Newcomer, K. (2010). Handbook of practical program evaluation. 3rd edition San Francisco: Jossey-Bass.

Xaxx, J. (2017). Website article on: The Impact of Communication on the Decision-Making Process in an Organization, http://smallbusiness.chron.com/impact-communication-decisionmaking-process-organization -24398.html (accessed 30.09). 